\title{
Identification and Characterization of Métiers in Multi-Species Artisanal Fisheries. A Case Study in Northwest Spain
}

\author{
Javier González-Álvarez ${ }^{1}$, Laura García-de-la-Fuente ${ }^{1}$, Lucía García-Flórez ${ }^{2}$, \\ Mª del Pino Fernández-Rueda ${ }^{2}$, Jorge Luis Alcázar-Álvarez² \\ ${ }^{1}$ INDUROT (Instituto de Recursos Naturales y Ordenación del Territorio), University of Oviedo, Mieres, Spain \\ ${ }^{2}$ CEP (Centro de Experimentación Pesquera), Regional Ministry of Rural Development and Natural Resources of \\ the Principality of Asturias, Gijón, Spain \\ Email: "laura.indurot@uniovi.es
}

Received 10 February 2016; accepted 10 June 2016; published 13 June 2016

Copyright (C) 2016 by authors and Scientific Research Publishing Inc.

This work is licensed under the Creative Commons Attribution International License (CC BY).

http://creativecommons.org/licenses/by/4.0/

(c) (i) Open Access

\begin{abstract}
Artisanal fisheries are characterized by using a vast array of different fishing gears and target species. Such heterogeneity has traditionally complicated their management and the availability of accurate data on fishing effort and incomes. This study identifies and characterizes the métiers currently used by an artisanal fishing fleet based in a coastal Atlantic region in South-Europe (Asturias, Northwest Spain), by applying an integrated method of analysis which combines administrative data on fishing licenses, daily sales statistics and information from surveys. As a result, 21 artisanal fishing métiers have been identified, with special relevance of the trammel net (targeting Lophius spp.), the Merluccius longline and the Merluccius gillnet métiers. Spatio-temporal patterns of fishing effort have been also described, and outputs and inputs demands per métier have been quantified. It has been also found a high degree of alternation between different métiers during the fishing season and significant differences in terms of technical aspects and workforce. Finally, fishermen's short- and long-term strategies (métier choice) are discussed, different comparisons are made on the basis of other South-European studies and main findings are linked to artisanal fisheries management.
\end{abstract}

\section{Keywords}

Métier, Artisanal Fisheries, Multi-Species Fleet Management, Bioeconomic Sustainability, North West Spain

\footnotetext{
${ }^{*}$ Corresponding author.
}

How to cite this paper: González-Álvarez, J., García-de-la-Fuente, L., García-Flórez, L., Fernández-Rueda, Mạ del P. and Alcázar-Álvarez, J.L. (2016) Identification and Characterization of Métiers in Multi-Species Artisanal Fisheries. A Case Study in Northwest Spain. Natural Resources, 7, 295-314. http://dx.doi.org/10.4236/nr.2016.76026 


\section{Introduction}

Despite their socioeconomic importance in many coastal communities, European artisanal fisheries have traditionally received less interest than industrial fisheries in marine and fisheries sciences. In fact, they, play a fundamental role in terms of human and territorial development at a local-regional scale [1]-[4]. In Spain, many studies have outlined that artisanal fisheries are suffering from a heavy decline in recent times [5] [6]. Although the high heterogeneity of these activities across different South-European countries and regions has impeded so far a standardized definition of these fisheries ${ }^{1}$ [2] [7]-[9], most of them are characterized by a high diversification in gears and fishing techniques and changing spatio-temporal patterns of their use. These features make difficult artisanal fishing management [2] [10]-[12].

In such a complex context, the concept of métier has been traditionally used to describe and characterize fisheries, as it is able to capture the major part of their heterogeneity [13]-[15]. Métier has been defined by European Decision 2008/949/CE ${ }^{2}$ as "a group of fishing operations targeting a similar (assemblage of) species, using similar gear, during the same period of the year and/or the same area and which are characterised by a similar exploitation pattern". Therefore, the concept of "métier" is closely linked to the fishing activities, patterns, traditions and gears employed by artisanal fishermen: each métier gathers a group of fishing operations defined by the combination of fishing gear, target species, area and season [11] [16], making up homogeneous units that summarize in a single variable the main characteristics of a large number of fishing trips [17].

As a consequence, a métier-based approach is very useful for understanding the spatio-temporal patterns of fishing effort allocation and resulting catches [10] [11]. Moreover, technical and bioeconomic characterization of fishing métiers is a basic step to accurately assess the real fishing effort and pressure exerted by artisanal and small-scale multi-specific fisheries. This understanding constitutes a key step for the improvement of economic and ecosystem fisheries management, as it helps to select appropriate management strategies and measures [12] [18] [19], and provides basic information to address marine spatial planning concerning artisanal fleets [20].

As Forcada et al. [10] have already acknowledged, identification of métiers has been widely based on the analysis of large historical datasets on species composition or catches data [17] [21]-[27]. The problem arises when such information is not available for artisanal fisheries. Recent research projects addressing métiers identification or applying a métier-based approach in the South-European area constitute illustrative examples of these limitations. On the one hand, the IBERMIX Project [28] was aimed at redefining and providing métier-disaggregated fishing data for the Spanish fleets operating in the Atlantic Iberian Peninsula waters oriented to ICES assessments and STECF mixed-fisheries management; as the segmentation was based on logbooks data, smallscale fleets were excluded from the analysis ${ }^{3}$. On the other hand, the TECTAC Project [29] has been aimed at addressing and supplying fisheries managers with a modelling tool to evaluate the impact of regulations on the dynamics of fleets and fishing mortality, on the basis of fishing tactics and strategies identification by métier. To do so, 30 demersal fleets from Denmark, the United Kingdom (England), the Netherlands, France and Spain were investigated, but in almost all the cases, vessels chosen for the project registered total length ranges above 10 - 12 metres, as well as a weak representativeness of so-called small-scale fisheries ${ }^{4}$.

In many cases identification and characterization of artisanal métiers have been carried out based on alternative approaches such as onboard samples or surveying methods [10] [11] [30]-[32], although researchers have also pointed out reliability problems that may arise when data elicited from resource users are employed [33]. Nevertheless, there is no precedent in exploring the potential of other sources of information to identify and characterize poor-data artisanal fisheries, as for example the administrative registers of fishing licences used by artisanal vessels: in many South-European coastal regions, artisanal vessels are required to communicate to fishing Administration each daily change in the fishing gears they used (equivalent to different artisanal fishing licences), so that it supplies an interesting source to be applied in monitoring their activity.

All these things considered, the main objective of this study has been to carry out a detailed and updated

\footnotetext{
${ }^{1}$ Achieving a standard definition of artisanal fisheries is a complex topic that exceeds the objective of this paper. A recent discussion in the South-European context can be found in García-Flórez et al. [9].

${ }^{2}$ Decision 2008/949/EC has been repealed with effect from 1 January 2011 by the Commission Decision 2010/93 of 18 December 2009, in which a multiannual Community Programme for the collection, management and use of data in the fisheries sector for the period 2011-2013 is adopted.

${ }^{3}$ Mainly, vessels registered as "artes menores" in the National Census of the Operating Fishing Fleet. This category embraces multi-gear vessels and it may be mainly assimilated to the "Only passive gears" European census category, although it may also include some other minor gears with a strong artisanal character and not necessary passive.

${ }^{4}$ Vessels selected consisted of Danish seiners, gill netters, long-lines, otter trawlers and beam trawlers.
} 
characterization of the main technical, biological and economic issues concerning the métiers used nowadays by the artisanal fishing fleet of Asturias, an Atlantic region located in Northwest Spain. To reach this goal, a novel approach using administrative data on fishing licenses combined with daily sales registers and information collected through a surveying process has been applied in order to: i) identify and classify the artisanal fishing métiers performed by the aforementioned fleet, ii) characterize their main technical, bioeconomic and temporal patterns, iii) provide basic information to improve decision-making processes and iv) discuss the relevance of the findings for the design of specific sustainable management measures in the context of South-European artisanal fisheries.

The present study has been part of a wider project about artisanal fishing fleets of the European Atlantic Arc (“PRESPO: Sustainable Development of Atlantic Arc Artisanal Fisheries”), developed between 2009 and 2012 within the Atlantic Area Transnational Cooperation Programme 2007-2013.

The structure of this article is as follows. Section 2 describes the case study and summarizes the data collection process, explaining the main characteristics of data sources used and the methodology applied, in order to identify and characterize the métiers. In Section 3 results are presented addressing the following topics: métier identification and classification, level of activity/use, alternation and seasonality, target species and species composition, weight and incomes per daily sale bill and, finally, technical and workforce demands associated to each métier. Last part of the article includes a chapter of discussion (Section 4) about the main results achieved linked to artisanal fisheries management and remaining constraints that need further research and a section. To conclude, Section 5 shows the main conclusions.

\section{Case Study Description, Material and Methods}

\subsection{Case Study}

This study was focused on the Principality of Asturias, an Atlantic region in Northwest Spain (Figure 1) that has $335 \mathrm{~km}$ of shoreline along the Cantabrian Sea and about one million inhabitants. Regional fishing grounds, take up 984,938 hectares ${ }^{5}$. A detailed description of this area was included in Garcia-de-la-Fuente et al. [12]. Asturian artisanal vessels are allowed to use a large range of traditional fishing gears such as trammel nets, longlines, traps, gill nets, etc., targeting many valuable species sold in local markets and changing frequently the fishing gears and techniques along the year [12]. These issues allow them to develop a highly adaptive and flexible activity in order to maximize profitability. On the other hand, the high variety and alternation between different métiers during the fishing season makes difficult to estimate with confidence fishing effort, real pressure over marine resources and coastal ecosystems, the performance of each fishery and any accurate economic indicator about the activity's return.

Regional experts and public administration agree to consider as artisanal at least those vessels registered as "artes menores" in the National Census of the Operating Fishing Fleet. This group comprises 233 boats $^{6}$ distributed along 19 ports from where they exploit areas that can be reached in a few hours. The average total length registered by this fleet is $8.8 \mathrm{~m}$, as well as a capacity of $4.5 \mathrm{GT}$ (gross tonnage) and an engine power of $51 \mathrm{~kW}$. Furthermore, vessels from other census categories are allowed to operate with a temporary "artes menores" license upon previous request to the regional fishing administration.

\subsection{Data Collection}

Official statistics, administrative data and information from a specific fishers' survey were used in this study. Administrative data on artisanal fishing modalities (licenses) used per day and vessel and daily sales bills ${ }^{7}$ of the artisanal fleet during 2009 have been exploited together to identify and characterize artisanal fishing métiers. Detailed information about total catch, including discards and unsold catches, was not available for this study.

The regional ministry with powers in marine fishing affairs establishes the fishing modalities (licenses) that can be used by the artisanal fleet. They present a high level of disaggregation, considering as different modalities those similar gears with minor technical differences (e.g. mesh size) and targeting different species. Although Asturian artisanal vessels are allowed to alternate between fishing modalities, they are requested to use

\footnotetext{
${ }^{5}$ Updated Asturian fishing grounds map, carried out in 2011 by the Regional Ministry with powers on fishing affairs. Available on line at http://tematico.asturias.es/dgpesca/din/divulgacion.php?tipo=caladeros.

${ }^{6}$ Data referred to June 2010.

${ }^{7}$ Commercial information per vessel concerning daily sales at local first-sale fish markets.
} 


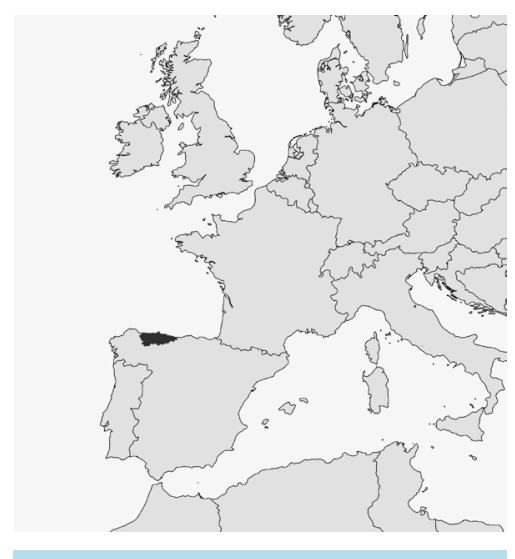

Figure 1. Map of the study area.

just one per fishing day and to communicate to the fishing administration any change in the modality used.

The analysis of both information sources resulted in an integrated database for $205^{8}$ vessels. A matrix was built from this database, whose rows represented daily sales bills per vessel (a total of 14,254 fishing operations or cases), while columns contained information about the vessel, fishing modality, landings weight (per species) and income obtained. Taking into account the activity patterns of the Asturian artisanal fleet [12], it was assumed that daily sales bills correspond to the landings and retained captures for commercial purposes of a single fishing day for the analyzed vessels.

As complementary source, a survey was carried out through face-to-face interviews with ship-owners and ship's masters, and information regarding the use of different métiers was applied for this research. Studies elsewhere using interview data show that this approach can produce highly valuable information for fisheries assessment [10] [12] [34]. The interviews were carried out between May 2009 and March 2010 following a stratified random sampling methodology based on the number of boats per fishing port in order to avoid overestimating the importance of highly located métiers [26]. As result, a total of 146 vessels from 18 Asturian fishing ports were interviewed, which implies coverage of $71.2 \%$ of the artisanal vessels with landings in 2009 . This sample was considered also representative by port: in 13 fishing ports, a sample covering between $40 \%$ - $64 \%$ of the local artisanal vessels was surveyed, while in other 2 fishing ports this coverage raised up to $73 \%$ and $88 \%$ respectively. Finally, only in 3 cases the sample was under the $30 \%$ of vessels based in the local fishing port. Among other issues ${ }^{9}$, in the questionnaire fishermen had to declare all the gears they used, specifying (per fishing gear) the month/s of the year, main target species, frequency of hauls (daily, other), percentage of total annual landings caught, fishing ground/s and distance from the coast to the fishing areas.

\subsection{Methodology for Métiers Identification and Characterization}

Métiers can be identified at different levels of aggregation, and depending on this, results obtained can vary (mainly in number). Literature on métiers identification outlines the importance of linking them to the target species; this question is especially relevant in artisanal métiers, as many of them target one specific species. On this basis, some limitations arise when a classification framework as the one included in Decision 2008/949/ $\mathrm{EC}^{10}[35]$ is taken as reference to identify artisanal fishing métier, as in many cases its maximum level of disaggregation (level 6, specifying gear type, species target assemblage and mesh size and other devices) does not allow reflecting all the rich and vast array (amount and variety) of artisanal métier. Thus, this research proposes the need of setting out alternative identification/classification frameworks with higher resolution and level of disaggregation. At the same time, it is desirable to put them in correspondence with European DCF.

To do so, this article proposes as novelty that administrative data on fishing licenses are used to get a highly detailed level of métiers practiced by artisanal fleets, taking into account that some fishing authorities (above all, at a local-regional scale) have developed management instruments well-fitted to particularities of the métier practiced by the artisanal fleets under their competence. Thus, the existing artisanal fishing modalities (adminis-

${ }^{8}$ Some of the supposedly active vessels in 2009-2010 (233) did not have sales in 2009.

${ }^{9}$ For more details, see the description in García-de-la-Fuente et al. [12].

${ }^{10}$ See Appendix IV, North Atlantic Region: ICES areas V-XIV and NAFO areas. 
trative licenses) were used to identify most of artisanal métiers in a first stage for the region studied. As a result, all those operations using the same fishing modality and targeting the same species were $a$ priori considered as constituting a distinct métier. On the other hand, during the interviewing process artisanal fishers highlighted that they used some of the existing fishing modalities to develop different fishing operations in terms of seasonality and objective species. Hence, in a second stage further métiers were identified thanks to the surveying process $^{11}$. This information was later confirmed by the analysis of daily sales data.

The final characterization of métiers was based on a) the administrative license used, b) species declared as targeted by the fishers during the interviews, c) the weight, income and species composition according to the sales register and d) the months of the year when most of the operations were carried out. To assess significant differences in landings and profitability, average weight and income per daily sales among the identified métiers were tested by one-way analysis of variance (ANOVA). However, given the large size sample $(24,254$ cases) and number of factors included in the analysis (16 different métiers), none of the analyses met the prerequisite of variance homogeneity (Levene's test for equality of variances) which is needed to address the ANOVA. Alternatively, a non-parametric Kruskal-Wallis test was applied ${ }^{12}$ using the software SPSS [36]: this test is well suited for testing whether sample populations come from the same distribution, does not assume normal distributions of the residuals for such samples and is suitable when outliers in data are suspected.

\subsection{Typology of Vessels per Métier}

Describing the different métiers may not be sufficient to understand the mechanisms involved in the dynamics of artisanal fishing activity [17]. Due to this, it is necessary to analyze not only the main fishing métiers at trip level, but to identify the scale and characteristics of vessels carrying out each different métiers and how those characteristics may influence fishing decisions and strategies. To do so, information from 205 vessels about boat total length, gross tonnage, engine power and crewmembers was collected from the National Census of the Operating Fishing Fleet and the Social Marine Institute respectively, which allowed estimating the average technical characteristics demanded per métier.

Finally, an ANOVA was carried out to test significant differences in such variables between the different métiers. When the normality and homogeneity of variance requisites were not met, log-transformation $x^{\prime}=\log (x$ +1) was applied (tonnage and crew members).

\section{Results}

\subsection{Métier Identification and Technical Classification}

In order to organize results according to European Data Collection Framework (2008/949/EC) [35], the identified métier are shown in correspondence with level 4 (gear type) of this regulation (Table 1). A total of 21 artisanal fishing métiers were identified ${ }^{13}$, using 8 types of fishing gears according to the aforementioned DCF. Of these métiers, 18 correspond directly to fishing modalities as established by the regional fishing administration, while 3 new métiers were identified (Conger longline, Nephrops trammel net and Homarus pot). Although these métiers are practiced under some of the existing fishing licenses, they target different species and present slight technical variations, which justifies considering them as a distinct métier. In order to identify and characterize these new three métiers within the daily sales bills database, all of those fishing days using longlines, trammel nets or pots in which the declared target species for these métiers (Conger conger, Nephrops norvegicus and Homarus gammarus) represented more than $40 \%$ of the total sales were considered to belong to the respective new identified métier.

The main métiers performed by the Asturian artisanal fleet in 2009 were Lophius spp. trammel net ${ }^{14}$ (31\% of the fishing days), Merluccius longline (19\%) and Merluccius gillnet (12\%). Other important métier were Octopus pot, Maja pot and Mullus trammel net.

\footnotetext{
${ }^{11}$ Although they were allowed to fish using the same administrative license.

${ }^{12}$ See Gibbons [37] for a detailed analogy and comparisons between non-parametric and parametric methods.

${ }^{13}$ Another three métiers linked to bait capture have been identified. However, these métiers have not been included in the analysis as they do not have any commercial interest.

${ }^{14}$ Although trammel net is considered a multi-species métier, Lophius spp. represents one of the main groups of target species according to the artisanal fishermen interviewed. Additionally, 2009 registered a high amount of Lophius spp. sales, with an important relative weight within the species composition of this métier. Taking these reasons into account, a specific reference to Lophius spp. trammel net is made in several parts of this article.
} 
Table 1. Métiers identified in the Asturian artisanal fleet, according to gear type categories established by the European DCF.

\begin{tabular}{|c|c|c|c|c|}
\hline \multirow{2}{*}{ Gear type (DCF) } & \multicolumn{2}{|c|}{ Identified métiers } & \multirow{2}{*}{ Target species } & \multirow{2}{*}{ No of fishing days in 2009} \\
\hline & Métiers & Local name & & \\
\hline \multirow{3}{*}{$\begin{array}{l}\text { Set longlines } \\
\text { (LLS) }\end{array}$} & Merluccius longline & Palangrillo & Merluccius merluccius & 2672 \\
\hline & Conger longline ${ }^{\mathrm{a}}$ & Palangrillo congrio $^{\mathrm{a}}$ & Conger conger & 562 \\
\hline & Dicentrarchus longline & Palangrillo lubina & Dicentrarchus labrax & 847 \\
\hline \multirow{3}{*}{$\begin{array}{l}\text { Hand and Pole } \\
\text { lines (LHP)/ } \\
\text { (LHM) }\end{array}$} & Rod-hook ${ }^{\mathrm{b}}$ & Pincho-caña ${ }^{\mathrm{b}}$ & Merluccius merluccius & 0 \\
\hline & Squid jig-hook & Potera & Loligo vulgaris & 731 \\
\hline & Rod-hook ${ }^{\mathrm{c}}$ & Anzuelo para caballa & Scomber scombrus & 278 \\
\hline \multirow{3}{*}{$\begin{array}{l}\text { Trammel net } \\
\text { (GTR) }\end{array}$} & Mullus trammel net & Trasmallo & Mullus surmuletus & 902 \\
\hline & Nephrops trammel net ${ }^{\mathrm{a}}$ & Trasmallo cigala $^{\mathrm{a}}$ & Nephrops norvegicus & 5 \\
\hline & Lophius tramelnet & Miño & Lophius spp. & 3012 \\
\hline \multirow{3}{*}{ Set gillnet (GNS) } & Mullus gillnet & Beta salmonetera & Mullus surmuletus & 629 \\
\hline & Merluccius gillnet & Beta & Merluccius merluccius & 1658 \\
\hline & Maja gillnet $^{\mathrm{b}}$ & Volanta marisquera $^{\mathrm{b}}$ & Maja squinado & 0 \\
\hline Driftnet (GND) & Driftnet $^{\mathrm{b}}$ & Abareque $^{\mathrm{b}}$ & Sardina pilchardus & 0 \\
\hline Purse seine (PS) & Purse seine ${ }^{\mathrm{b}}$ & Cerco chicharro $^{\mathrm{b}}$ & Trachurus trachurus & 0 \\
\hline \multirow{4}{*}{$\begin{array}{l}\text { Pots and traps } \\
\text { (FPO) }\end{array}$} & Octopus pot & Nasa pulpo & Octopus vulgaris & 880 \\
\hline & Maja pot & Nasa marisco & Maja squinado & 1203 \\
\hline & Homarus pot ${ }^{\mathrm{a}}$ & Nasa bugre $^{\mathrm{a}}$ & Homarus gammarus & 163 \\
\hline & Anguilla pot & Nasa butrón & Anguilla anguilla & 3 \\
\hline \multirow{3}{*}{ Miscellaneous } & Glass eel & Cedazo & Anguilla anguilla & 689 \\
\hline & Seaweed & Algas & Gelidium spp & 0 \\
\hline & Mirror & Espejo & Maja squinado & 19 \\
\hline TOTAL & \multicolumn{2}{|c|}{$\begin{array}{l}21 \text { métiers identified. } \\
16 \text { métiers currently active }\end{array}$} & $\begin{array}{l}11 \text { target species linked } \\
\text { to the active métiers }{ }^{\mathrm{d}}\end{array}$ & 14,254 fishing days \\
\hline
\end{tabular}

${ }^{\mathrm{a}}$ Métiers identified through the fishers' survey. ${ }^{\mathrm{b}}$ Artisanal métiers allowed by existing fishing modalities but that were not practiced by the artisanal fleet in 2009. 'Unlike the "Rod-hook" métier targeting Merluccius merluccius, in the "Rod-hook" métier targeting Scomber scombrus artificial bait is used. ' Merluccius merluccius; Conger conger; Dicentrarchus labrax; Loligo vulgaris; Scomber scombrus; Mullus surmuletus; Nephrops norvegicus; Lophius spp.; Octopus vulgaris; Anguilla Anguilla; Gelidium spp.

On the other hand, at least four of the potential métiers ${ }^{15}$ were not carried out by the artisanal fleet during 2009 (Merluccius rod-hook, Maja gillnet, driftnet, purse seine), while some others were only used by few vessels (mirror, Nephrops trammel net and Anguilla pot). In terms of gear types, longlines were the most used gears (29\% of fishing operations), followed by trammel nets (27\%) and gillnets and traps (both with $16 \%$ of fishing operations).

In addition to the problem of low information and poor knowledge in artisanal fleets, these results confirm the heterogeneity of a sector (the artisanal one) that frequently has been globally treated "as a whole" and classified within an only and undifferentiated national census category, which usually has been taken as a reference for management and planning public policies at a national and European scale. As the present case study has revealed, artisanal fleets actually comprehend a miscellaneous group of fishing modalities mainly practiced by multi-gear vessels with high differences in terms of gears, target species and level of practice within the artisanal fleet itself. As result, their internal complexity and heterogeneous structure should be taken into account when management measures are designed and implemented in those regions where artisanal vessels represent a rele-

\footnotetext{
${ }^{15}$ It is impossible to assess the number of sale notes considered as fishing days for the seaweed recollection métier as these sales are not considered as a fishing resource and, consequently, are no registered on the sales database. However, it is known that just one artisanal vessel operated with such fishing modality in 2009.
} 
vant percentage of the total fleet.

Nevertheless, information gathered through the interviewing process was useful to understand the conditions and fishing strategies that influence fishers' decisions on what métiers should be used on a short and long term perspective. Thus, fishers' survey revealed that artisanal fishing patterns have changed significantly over the last years, and it is expected that their evolution will continue through the coming years. Certain métiers such as rod-hook, seaweed recollection or purse-seine are currently only practiced by vessels from other census categories that request to operate with "artisanal gears" temporally, while other métiers are quickly reducing their levels of activity in Asturias. As result, only $76 \%$ of the identified métiers can be considered active nowadays. Moreover, a trend of progressive reduction in the diversity of métiers practiced by this fleet in the last years has been confirmed: due to changes in fishing strategies and variations in fishers' rational behavior to maximize activity's profitability, in recent times net métiers (as for example Lophius tramelnet, Mullus trammel net and Merluccius gillnet) are getting higher presence and replacing other traditional ones.

Finally, in addition to the identified fishing métiers it must be also mentioned the goose barnacle (Pollicipes pollicipes) recollection, as an important complementary fishing activity for artisanal fishermen in the central and west coast of Asturias, especially from October to April, when other fishing possibilities are scarce. Even though this activity cannot be considered as a métier (it is a harvesting activity carried out through a personal seafood recollection license), a large number of vessels crewmembers alternate goose barnacle recollection with other fishing métiers considered compatible ${ }^{16}$. As a consequence, the vessel remains inactive for certain periods of time when all the crewmembers are dedicated to the recollection activity and the obtained incomes are distributed among the crew ${ }^{17}$.

\subsection{Métiers Alternation and Spatio-Temporal Distribution}

Artisanal vessels have shown a high degree of alternation between different métiers along the year. Results in Figure 2 confirm the multi-specific and multi-gear character of the Asturian artisanal fleet, as in 2009 the 55\% of artisanal vessels practiced 3 or more different métiers. This high flexibility is also observed in terms of fishing gears alternation, with $18.4 \%$ of boats using métiers corresponding to 3 or more different gear types. The annual mean number of métiers practiced was 2.89 (with a standard deviation of \pm 1.23 ). These findings reflect that annual fishing effort is distributed among an "optimal" combination of métiers for each vessel, and a certain degree of "substitution effect" among métiers exists.

Analyzing the spatio-temporal distribution of the métiers, it can be observed (Table 2) that the main métiers in terms of annual number of fishing days (Lophius spp. trammel net and Merluccius longline) are present along the majority of the Asturian fishing ports during most part of the year. In general terms, most ports use a highly diversified array of métiers, although some of them appear to be "specialized" (Figure 3) in certain types of fishing gears (e.g. in Bañugues only pot gears are utilized, while $60 \%$ of the fishing operations in Puerto de Vega are carried out using longlines). On the other hand, métiers carried out in shallow waters close to the shore and in estuaries targeting crustaceans (pots and Mirror), cephalopods (Octopus pot) or anguilliformes (Anguilla pot and glass eel fishing) show a highly seasonal pattern (Figure 4), being generally located in a few ports with a long tradition in the utilization of these type of métiers.

These latter métiers (and the mentioned goose barnacle recollection) are not only a clear expression of the traditional fishing gears performed by the regional fleet, but they also play a fundamental role as a complementary fishing activity during certain periods of the year when it is not possible to carry out other métiers. This is especially important between January and March, when longlines use to be inactive as the adverse weather conditions do not allow the gear to be operated efficiently.

\subsection{Output Analysis: Weight, Income and Species Composition per Métier}

In the 14,254 cases analyzed, a total of 115 commercial species were registered, even though only 11 have been identified as target for the 16 active métiers (Table 1). Although most of them were fishes, crustaceans (Maja squinado, Homarus gammarus, Necora puber, etc.) and cephalopods (Octopus vulgaris, Loligo vulgaris) were also recorded. The species with the highest market value was Anguilla anguilla (glass eel), followed by several crustaceans (Scyllarus arctus, Palinurus elephas and Palaemon serratus); although, landings of such species are

\footnotetext{
${ }^{16}$ Those daily set and hauled, and always practiced in different days as goose barnacle recollection.

${ }^{17}$ Nevertheless, crewmembers keep the same retribution pattern and benefits share that when they fish using the vessel.
} 


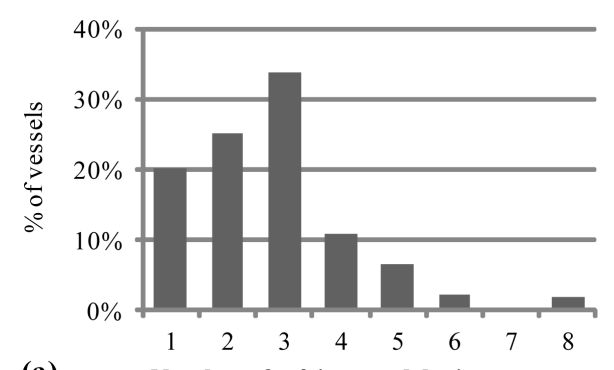

(a)

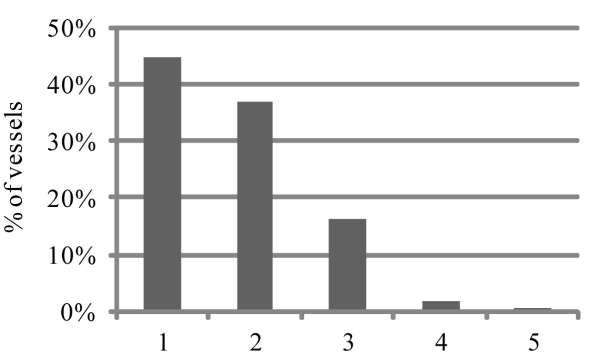

(b)

Number of gear types used during a year

Figure 2. Number of métiers (a) and gears types (b) practiced per vessels over a one-year period (in percentage).

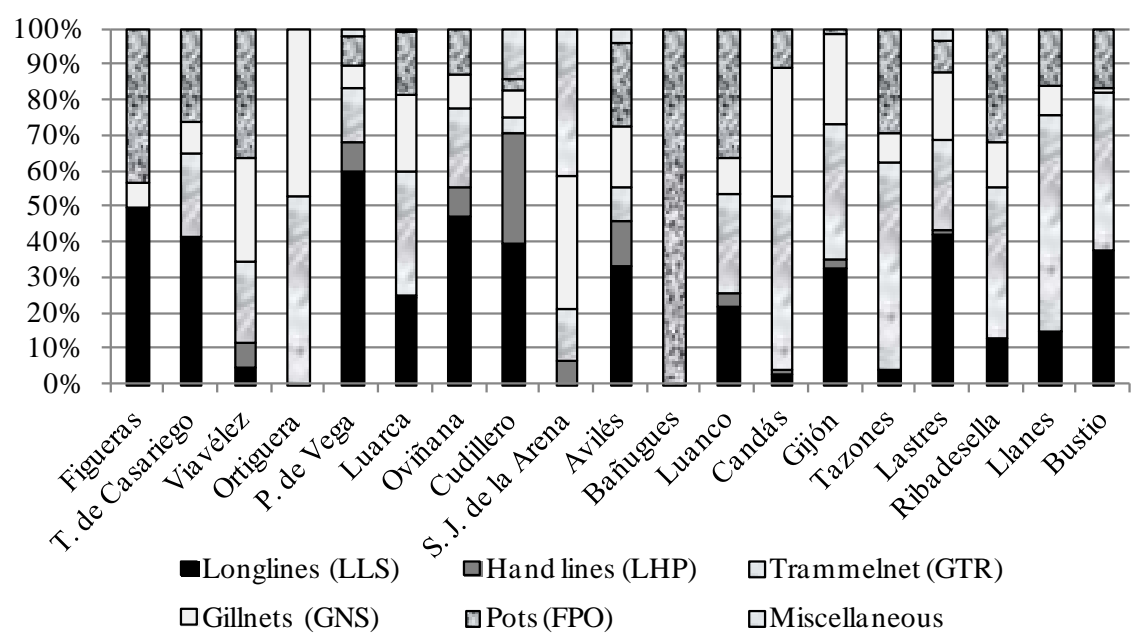

Figure 3. Degree of utilization of the different gear types by fishing port (in percentage).
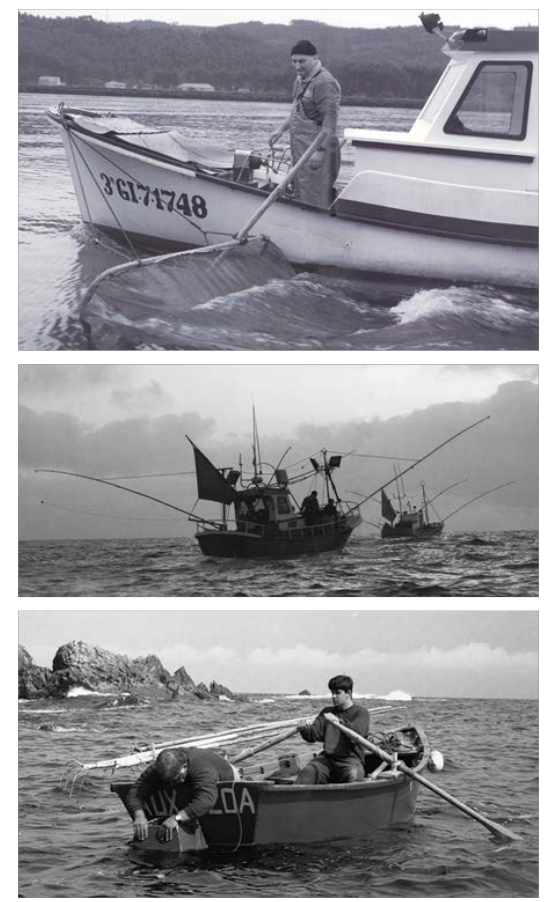

Figure 4. Artisanal métiers practiced in the Asturian coastline. From the top to the bottom, Glass eel, Rod-hook targeting Merluccius merluccius and Mirror. 
Table 2. Main characteristics of the artisanal active métiers in 2009.

\begin{tabular}{|c|c|c|c|c|c|c|c|c|c|c|c|c|c|c|c|c|c|c|}
\hline \multirow{2}{*}{ Métier } & \multirow{2}{*}{$\begin{array}{l}\text { Type of } \\
\text { bottom }^{\text {a }}\end{array}$} & \multirow{2}{*}{$\begin{array}{c}\text { Average } \\
\text { catch }(\mathrm{kg}) \\
\text { per sale bill }\end{array}$} & \multirow{2}{*}{$\begin{array}{c}\text { Average } \\
\text { income }(€) \\
\text { per sale bill }\end{array}$} & \multirow{2}{*}{$\begin{array}{l}\% \text { of } \\
\text { fishing } \\
\text { days }\end{array}$} & \multirow{2}{*}{$\begin{array}{l}\text { No of fishing } \\
\text { vessels using } \\
\text { it }\end{array}$} & \multirow{2}{*}{$\begin{array}{l}\text { No of } \\
\text { fishing } \\
\text { ports }\end{array}$} & \multicolumn{12}{|c|}{ Seasonality } \\
\hline & & & & & & & $\mathrm{J}$ & $\mathrm{F}$ & M & A & M & $\mathrm{J}$ & $\mathrm{J}$ & A & S & $\mathrm{O}$ & $\mathrm{N}$ & D \\
\hline Merluccius longline & $\mathrm{R}, \mathrm{M}$ & 70.08 & 433.97 & $18.75 \%$ & 66 & 16 & & & & & & & & & & & & \\
\hline Conger longline & $\mathrm{R}$ & 126.26 & 304.29 & $3.94 \%$ & 33 & 11 & & & & & & & & & & & & \\
\hline Dicentrarchus longline & $\mathrm{R}$ & 75.15 & 359.26 & $5.94 \%$ & 20 & 8 & & & & & & & & & & & & \\
\hline Squid jig-hook & R, S & 34.23 & 300.14 & $5.13 \%$ & 36 & 8 & & & & & & & & & & & & \\
\hline Scomber rod-hook & A & 1468.23 & 885.69 & $1.95 \%$ & 13 & 7 & & & & & & & & & & & & \\
\hline Mullus trammel net & $\mathrm{R}, \mathrm{RT}$ & 67.25 & 240.50 & $6.33 \%$ & 22 & 9 & & & & & & & & & & & & \\
\hline Nephrops trammel net & M & 55.70 & 387.94 & $0.04 \%$ & 2 & 1 & & & & & & & & & & & & \\
\hline Lophius trammel net & S, M & 72.28 & 422.93 & $21.13 \%$ & 61 & 16 & & & & & & & & & & & & \\
\hline Mullus gillnet & $\mathrm{S}$ & 41.61 & 240.50 & $4.41 \%$ & 16 & 8 & & & & & & & & & & & & \\
\hline Merluccius gillnet & S, M & 116.24 & 425.35 & $11.63 \%$ & 40 & 14 & & & & & & & & & & & & \\
\hline Octopus pot & A & 56.42 & 275.34 & $6.17 \%$ & 38 & 7 & & & & & & & & & & & & \\
\hline Maja pot & $\mathrm{R}$ & 31.56 & 295.65 & $8.44 \%$ & 32 & 16 & & & & & & & & & & & & \\
\hline Homarus pot & $\mathrm{R}, \mathrm{RT}$ & 29.80 & 428.19 & $1.14 \%$ & 28 & 12 & & & & & & & & & & & & \\
\hline Anguilla pot ${ }^{\mathrm{b}}$ & - & 54.66 & 458.66 & $0.02 \%$ & 1 & 1 & & & & & & & & & & & & \\
\hline Glass eel $^{\mathrm{b}}$ & - & 4.75 & 323.85 & $4.83 \%$ & 40 & 5 & & & & & & & & & & & & \\
\hline Mirror & $\mathrm{R}$ & 8.64 & 185.63 & $0.13 \%$ & 1 & 1 & & & & & & & & & & & & \\
\hline
\end{tabular}

${ }^{\mathrm{a}}$ Type of bottom (R, rocky bottoms; S, sandy bottoms; M, muddy bottoms; RT, mixture of rocky and sandy bottoms; A, All types of bottoms); Seasonality (no shading, no use or residual use; light green shading, moderate use; dark green shading, intensive use). ${ }^{\text {b}}$ Fished on estuaries.

relatively low in terms of weight, crustaceans total (real) landings are likely higher because a part is commercialized out of fish markets (direct sale). Other species with lower market prices contributed in a higher proportion to the total income of the artisanal fleet (Merluccius merluccius, Scomber scombrus, Mullus surmuletus).

Average weight per sale bill was $99.19 \mathrm{~kg}$ (s.d. \pm 382.78) in 2009, while the average income per fishing day was $€ 396.65$ (with a standard deviation of $€ 454.82$ ). The analyzed métiers significantly differed in the average values of both parameters (catches Kruskal-Wallis, $\chi^{2}=4246.78, \mathrm{df}=15, \mathrm{P}<0.001$; incomes Kruskal-Wallis, $\chi^{2}$ $=862.69, \mathrm{df}=15, \mathrm{P}<0.001$ ). Given that under the null hypothesis of the Kruskal-Wallis test the mean ranks of the groups are the same, p-values obtained (under 0.05 ) lead to reject this assumption and confirm that significant differences exist between the analyzed métiers in terms of landings and incomes. As daily sale bills do not include discards or unsold captures, weight values presented through this section cannot be taken as a precise indicator of the total fishing effort exerted by the artisanal fisheries over the marine resources; notwithstanding, it is a highly valuable information regarding the economic activity of the artisanal vessels and the expected returns of the performed métiers in terms of species composition retained for sale, weight and incomes.

The rod-hook targeting Scomber scombrus is the métier that generates the highest weight landed and income per fishing day, significantly greater than the rest of métiers (Table 2). Notwithstanding, its use is reduced to a few months (or even a few weeks) between February and May, depending on the migratory patterns of the objective species (Scomber scombrus) and, mainly, the existence of Total Allowable Catch (TAC) established at a EU level. On the other hand, the versatility (possibility of been carried out at least 7 months per year), highcatch and income profile of the Lophius trammel net and the Merluccius longline métiers explain their high degree of utilization by the Asturian artisanal vessels. The significant commercial value (first sale prices) of Lophius spp. and $M$. merluccius (about $6 € / \mathrm{kg}$ both species) assures a relatively good income to vessels operating 
with Lophius trammel net and Merluccius longline (an average income of $€ 422.93$ and $€ 433.97$ respectively per fishing day). Other métiers used through most of the year are the Conger and Dicentrarchus longline and the Merluccius gillnet, that also show relatively high average incomes per fishing day, ranging from €300 to €425 (about 2.4 and $3.6 € / \mathrm{kg}$ respectively).

Although for most of métiers the largest sales in terms of weight correspond to the declared target species, for certain métiers (such as Maja and Homarus pot, Glass eel or Nephrops trammel net), the target species (with high first-sale prices) also constituted the highest contribution in terms of income. The species composition for the 5 most abundant commercial species of the 4 main métiers are presented in Figure 5 . As it can be observed, while the three first métiers show a more even distribution of landings, $90.8 \%$ of the Octopus pot catches retained for sale correspond to the target species. Although significant differences do exist in terms of selectivity among the métiers performed by the Asturian artisanal fleet, in all cases the five most important species represented at least the $50 \%$ of the total annual weight landed or income; nevertheless, results achieved can be used for stakeholders to work in favour of gears selectivity improvements for the main species retained for commercial purposes.

\subsection{Technical and Workforce Demands Associated to Each Métier}

In order to better understand artisanal activity and exploitation patterns, technical and workforce demands per
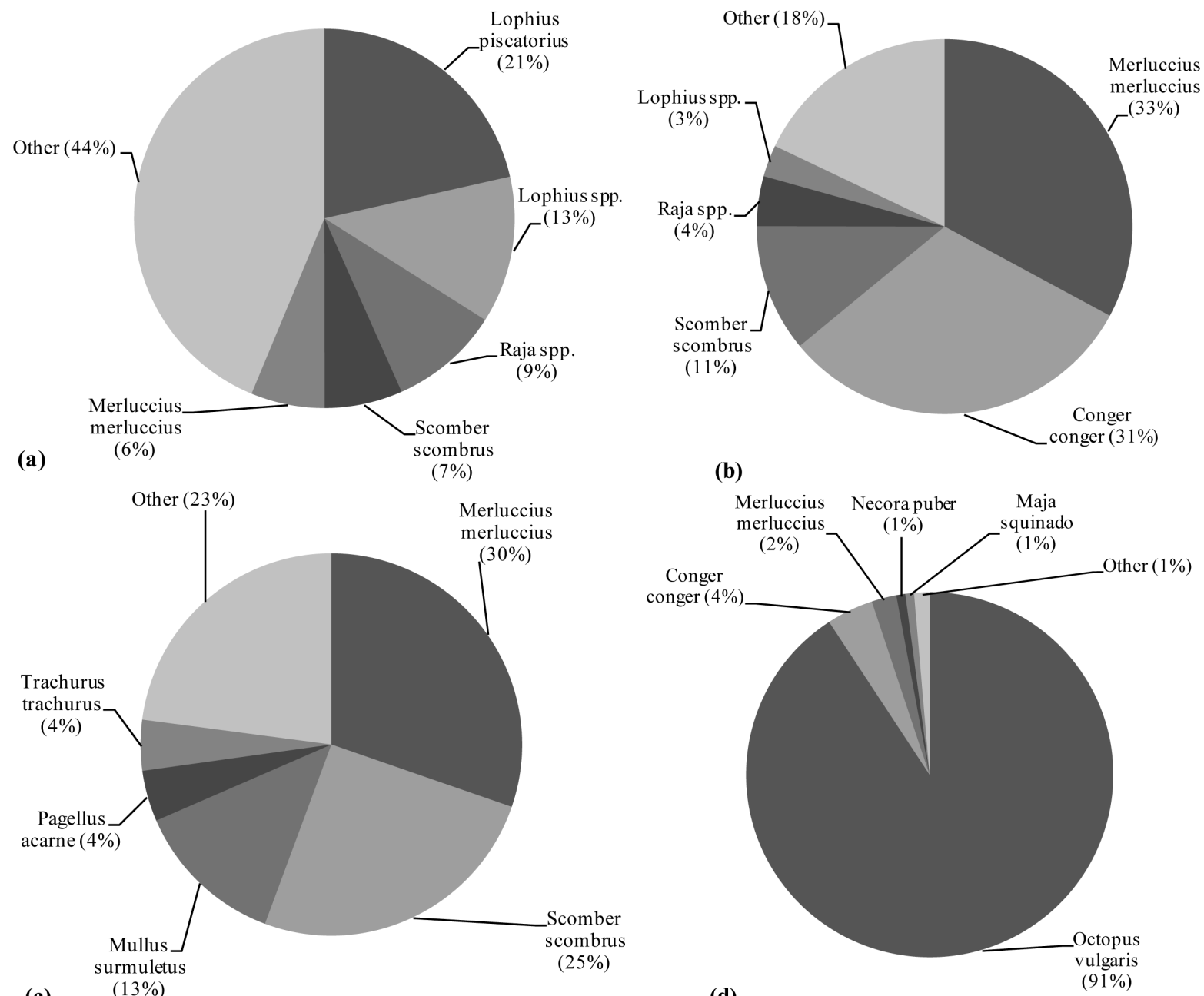

(b)

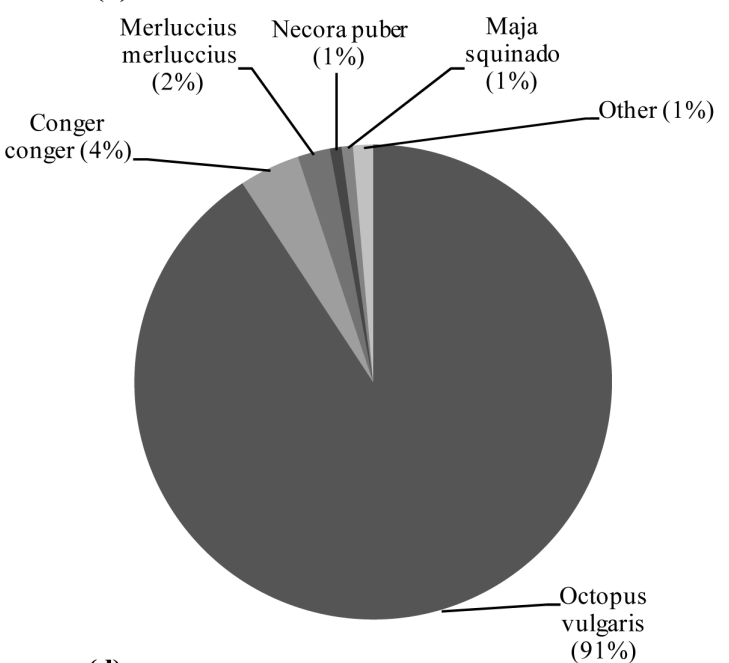

(d)

Figure 5. Species composition for the 5 most abundant commercial species of the 4 main identified métiers corresponding to 4 different gear types: (a) trammel net (“miño”), (b) Merluccius longline (“palangrillo”), (c) Merluccius gillnet ("beta”) and (d) Octopus pot ("nasa de pulpo"). 
métiers were studied, as they may determine vessels' possibilities to use some of them and such vessels may be forced to perform lower-income fishing activities throughout some periods of the year.

Achieved results allow more accurate inferences about costs structures and output models for this fleet at a métier level: both technical and workforce (number of crewmembers) characteristics significantly differ depending on the métiers (Table 3). Rod-hook targeting Scomber scombrus presents the higher demands (Figure 6) in terms of vessels total length (12.32 m), engine power (98.9 kW) and gross tonnage (11.55 GT), as a direct consequence of this fishery exploitation patterns: longer distance travels and large captures per fishing day (an average of $1468.23 \mathrm{~kg}$, Table 2).

Vessels targeting mainly crustaceans and glass eel present the opposite typology: small vessels with low gross tonnage, engine power and crewmembers that develop their activity in shallow waters close to their respective fishing ports. Such small vessels may find difficulties to assure a stable income level throughout the year, as they focused on highly seasonal métiers and vessels' characteristics may limit the capacity of performing other métiers for which different technical characteristics are required. In general terms, it can be observed that vessels using trolling lines show the highest technical parameters, followed by vessels using trammel net métiers, gillnets, longlines and, finally, pots and other gears.

\section{Discussion}

The concept of artisanal métiers actually embraces a highly diverse group of fishing modalities practiced by multi-gear vessels with a high variety of fishing operations, landings, incomes and spatio-temporal patterns. Many South-European artisanal fleets are mainly integrated by vessels under 12 and 10 metres of total length ${ }^{18}$; according to Regulation (CE) 1224/2009, these vessels are no subjects to comply with VMS and logbooks fill-in requirements respectively, which derives in a lack of monitoring systems that provide accurate, reliable and quantitative information on spatial and temporal fishing patterns for most of artisanal vessels ${ }^{19}$. This situation

Table 3. Summary of the one-way ANOVA for technical characteristics among the artisanal métiers identified ${ }^{\mathrm{a}}$.

\begin{tabular}{|c|c|c|c|c|c|c|}
\hline Vessel characteristics & Transformation & & Sum of squares & d.f. & Mean squares & $\mathrm{F}$ \\
\hline \multirow{3}{*}{ Length (m) } & \multirow{3}{*}{-} & Among groups & $15,645.24$ & 15 & 1043.02 & $315.37^{* * *}$ \\
\hline & & Within groups & $47,089.49$ & 14,238 & 3.31 & \\
\hline & & Total & $62,734.73$ & 14,253 & & \\
\hline \multirow{3}{*}{ Engine power (kW) } & \multirow{3}{*}{-} & Among groups & $1,796,675.25$ & 15 & $119,778.35$ & $105.91^{* * *}$ \\
\hline & & Within groups & $16,102,276.83$ & 14,238 & 1130.94 & \\
\hline & & Total & $17,898,952.08$ & 14,253 & & \\
\hline \multirow{3}{*}{ Tonnage (GT) } & \multirow{3}{*}{$\ln (x+1)$} & Among groups & $56,611.49$ & 15 & 3774.10 & $152.42^{* * * *}$ \\
\hline & & Within groups & $352,543.27$ & 14,238 & 24.76 & \\
\hline & & Total & $409,154.76$ & 14,253 & & \\
\hline \multirow{3}{*}{ Crewmembers } & \multirow{3}{*}{$\ln (x+1)$} & Among groups & 2520.76 & 15 & 168.05 & $230.58^{* * *}$ \\
\hline & & Within groups & $10,022.15$ & 13,751 & 0.73 & \\
\hline & & Total & $12,542.91$ & 13,766 & & \\
\hline
\end{tabular}

${ }_{\mathrm{a}}^{\mathrm{a}}=14,254$ (13,766 for crew members' analysis); d.f., degrees of freedom; F, F-Ratio, P, level of significance $\left({ }^{* * *} \mathrm{p}<0.001\right)$. A dash $(-)$ indicates no transformation.

${ }^{18}$ As example, in this case study, 212 of the total 233 artisanal vessels belonging to the “Artes menores” National Census category were under 12 metres of total length (91\%), and 157 were under 10 metres (67\%). Similar situations can be found in other South-European regions with large artisanal fishing fleets, as it has been recently outlined in García-Flórez et al. [9].

${ }^{19}$ In the case of Spain, during the last years many regions and fishing authorities have been making an effort to install positioning systems on board vessels less than 12 metres of total length, but current coverage is already partial and highly variable depending on the area and métier Additionally, these data are not directly available for research objectives and need to be previously processed. 
(a)

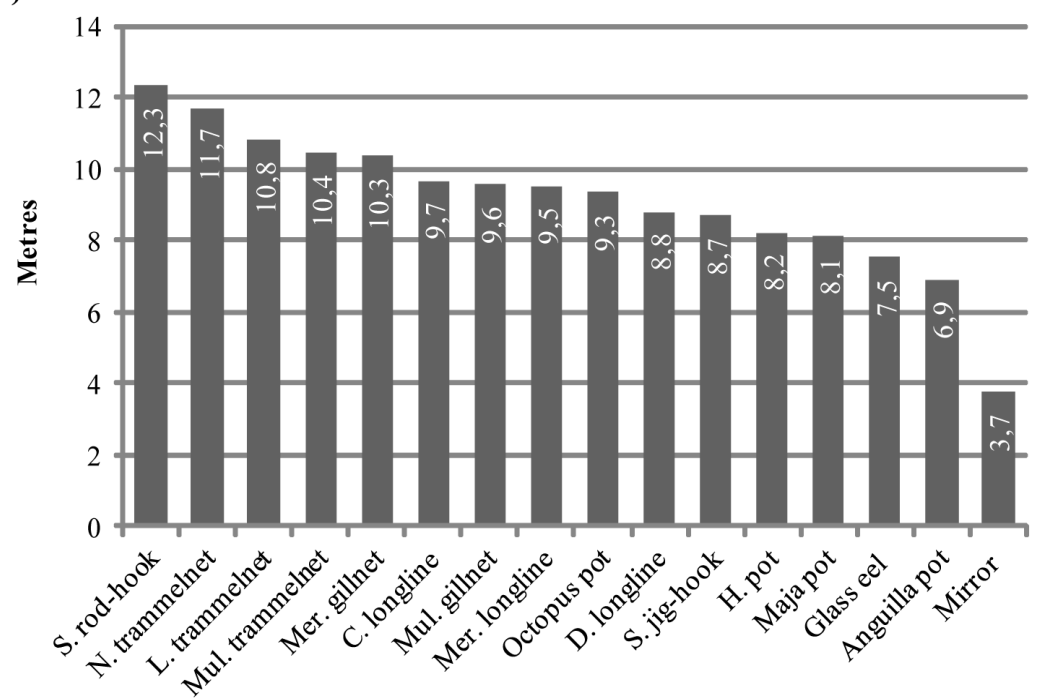

(b)

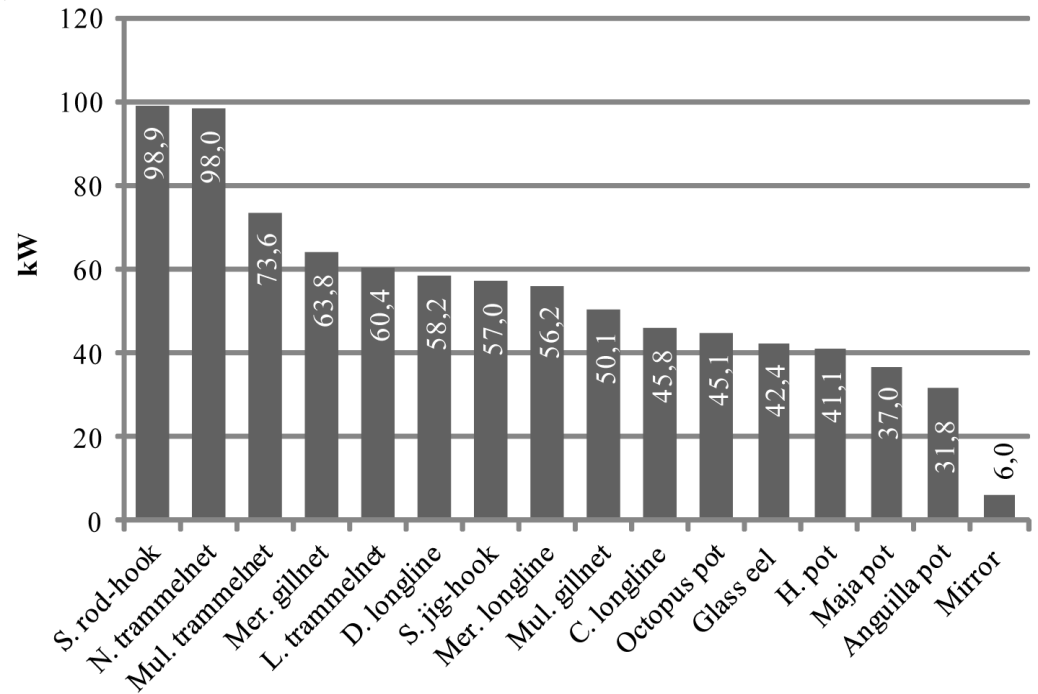

(c)

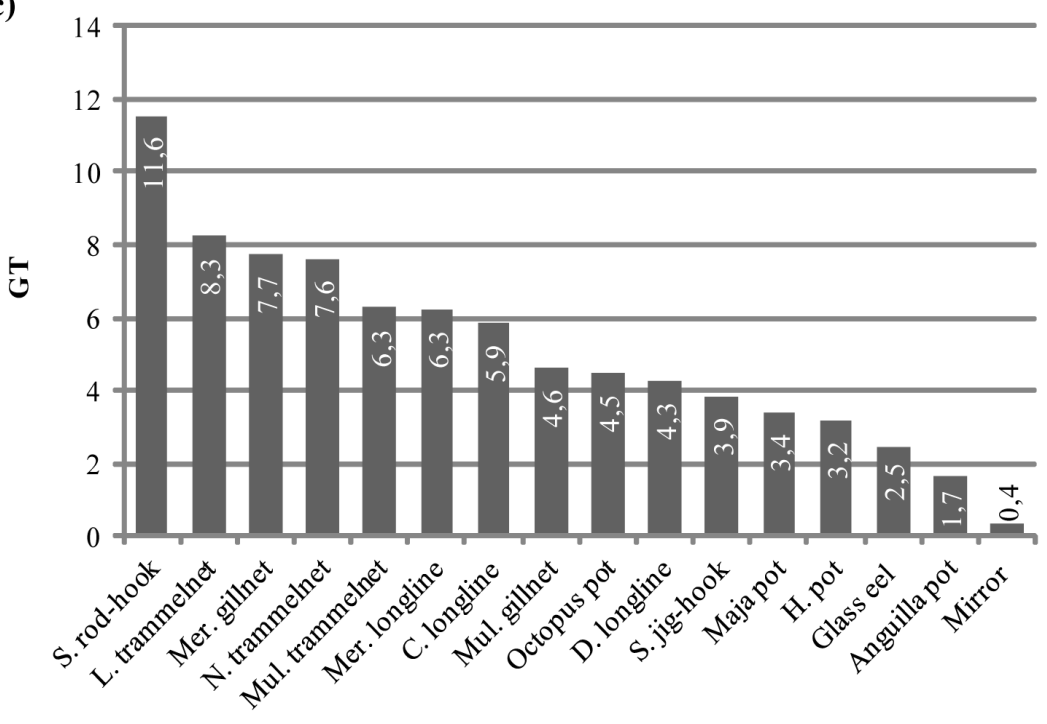


(d)

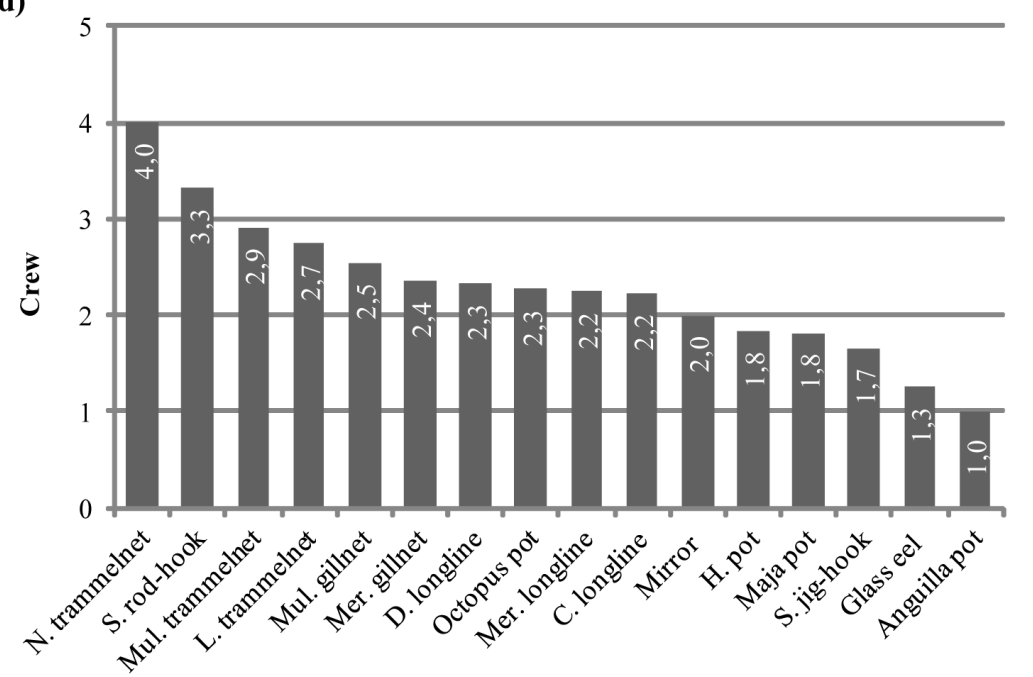

Figure 6. Average technical characteristics of artisanal vessels: (a) total length, (b) engine power, (c) tonnage and (d) crewmembers] according to the métiers performed.

has traditionally complicated a sustainable management of these boats, as basic and detailed data on their activity is not available. Usually in this context, first-sales notes become the only systematic source of information, although it allows analyzing neither spatial issues nor duration of fishing operations, so fishing effort and its location are mainly unknown for these fleets. On the other hand, information from specific monitoring surveys on vessels less than 12 metres of total length and voluntary collaboration of fishermen in data collection processes also represent an interesting complementary data source for artisanal vessels, but with important limitations (lack of accuracy and reliability of quantitative information, spatial information mainly qualitative and poorly detailed, etc.). Although some research projects, as IBERMIX [28] or TECTAC [29] have addressed the problem of identifying métiers in the South-European area, the aforementioned limitations on fishing data concerning vessels less than 12 metres have excluded most of artisanal boats from these relevant analyses so far.

This situation has traditionally hampered the design and implementation of specific management measures based on a good knowledge on the characteristics and problems of each métier. At the same time, South-European Atlantic regions as Asturias are registering a progressive disappearance of artisanal métiers with low economic profitability (although with high level of environmental and social sustainability), in parallel to a concentration process of artisanal fishing activities on a few main métiers.

Although previous studies also used the information from daily sales and direct interviews to fishermen in order to identify métiers [3] [10] [18] [24] [26] [32] [38]-[40], this research proposes a methodological novelty based on the detailed monitoring of the regional administrative register of artisanal fishing licences used per day and vessel in the region of study. A value added of this approach, in poor-data contexts, is that it allows reaching a highly-disaggregated and detailed artisanal metier identification and classification, that comprehends all the richness and diversity of métiers practiced by these type of boats, and provides higher resolution than other classification frameworks as the European Data Collection Framework (DCF-2008/949/EC).

Data mining of daily changes in fishing licences used by the artisanal regional fleet presents analytic advantages linked to the richness and high level of detailed data (per day and vessel) recorded, that avoids the lack of precision frequently derived from fishermen interviews and provides a large panel of accurate information that allows a quick preliminary identification of the most important métiers, as well as their main characteristics in terms of target species, fishing gears, monthly temporal pattern and level of rotation. After that, complementary information from daily sale bills, official fleet census and interviews was used to check, adjust and extent results in terms of catches retained for commercial purposes (species composition and weight), incomes, technical demands and fishing strategies per métier.

Although a precedent study carried out by Punzón et al. [41] provided a basic description of the artisanal fisheries in this area, it was focused on fishing gears, catches and their seasonality using information dated in 1996. From an empirical point of view, the present study provides an in-depth and updated characterization of 
the metiers practiced by the artisanal fleet in the region studied (Asturias, Northwest Spain), with high level of resolution and showing how artisanal activity is changing in recent times (trend of concentration in some métiers and cease of another).

The Asturian fleet is mainly artisanal, involving over 230 vessels (205 vessels with sales in 2009) that represent around $70 \%$ of the whole fleet. This sector has a great socioeconomic, cultural and historical importance given the strong bonds between the coastal communities, the artisanal fisheries and the marine environment [1]-[4] [12]. The large number of métiers identified in this study (21 métiers, 16 of which were active in 2009) is a direct consequence of the coastal, close-to-port character of the Asturian artisanal fisheries. As several studies have highlighted, the use of fixed fishing gears in coastal areas, where seasonal environmental variability and spatial heterogeneity are high, promotes the diversification of fishing tactics [10] [11]. Results from this case study confirm the real heterogeneity of vessels that usually are grouped together within the same category (named "Artes menores" in Spain, "Only passive gears" at a European scale, etc.), which is treated as a "uniform" census modality by management and planning public policies. As a consequence, in those regions where artisanal vessels belong to these census categories and represent a relevant part of the total fleet, management measures should be designed and implemented taking into account métiers heterogeneity and the high level of internal complexity of artisanal fleets.

As it occurs in another artisanal and small-scale fisheries in South Europe [10] [11] [31] [32] [38] [39] [42], findings concerning the high annual rotation of fishing métiers and gears types confirm that polyvalence and versatility ${ }^{20}$ are important features of artisanal fleets, representing the fishermen's ability to adapt, up to some extent, to dynamic environmental conditions and to different presence of resources in order to ensure stability in landings and sustain returns throughout the whole year.

Two interesting conclusions arise from these findings. Firstly, when métiers rotation exists, a certain degree of "substitution effect" among métiers exists, which must be interpreted as a strength and taken into account for artisanal fleets subsidies design; in these cases, a percentage of negative effects from changes in fish stocks, limitations of captures or increases in costs can be softened. In opposition to this, the practice of métiers with low possibilities of replacement among each other introduces rigidity in fishing strategies and reduces adaptation possibilities for the fleet, which should be considered by managers. This research has confirmed that some smaller vessels have constraints to redistribute their fishing effort, especially in those periods of worst weather conditions: some artisanal métiers identified, as the glass eel fishing, and other fishing activities as the goose barnacle (Pollicipes pollicipes) recollection, play a fundamental role as alternative fishing activities during certain periods when it is difficult and unprofitable to carry out another métiers (i.e. first months of the year when longlines use to be inactive because of bad weather conditions). In terms of sustainable management of artisanal fisheries, this kind of métiers should be prioritized by sectoral support measures, as they have strong socioeconomic effects at a local scale, play an important subsidiary role in such periods (when other métiers cannot be practiced) and contribute, as a result, to the stability of artisanal fishermen revenues along the year.

Nonetheless, despite their polyvalent character, certain métiers are used extensively by the artisanal fleet producing the major part of landings and revenues of these vessels: Lophius trammel net and Merluccius longline generates the $28.6 \%$ of landings and $43.1 \%$ of the total income generated by artisanal fisheries in 2009. It is worth highlighting that trammel net is one of the most representative artisanal gears across European small-scale fisheries [2] [10] [11] [32] [39] [40] [43]-[45]. However, while most Mediterranean trammel nets artisanal métiers target species such as scorpion fishes (Scorpaena spp.), red mullets (M. surmuletus), European hake ( $M$. merluccius) or cuttlefish (S. officinalis), the trammel net mostly used by Asturian artisanal vessels target mainly Lophius spp. and Raja spp., although landings of M. surmuletus and M. merluccius are also recorded. Identified Mullus trammel net and Merluccius gillnet are also widely used by the aforementioned Mediterranean artisanal fisheries.

On the other hand, although the use of longlines have been reported for several Mediterranean fisheries [10] [11] [38] [46] targeting mainly sea breams (Sparidae), their degree of use is clearly lower than shown for the Asturian artisanal fleet (used in $28.63 \%$ of the total fishing days). This specific gear targeting European hake ( $M$. merluccius) and conger (C. conger) seems to be more common among Atlantic artisanal fisheries [47].

In terms of spatial distribution, the identified métiers are located in several fishing ports covering broad geographical areas. In fact, 12 of the active métiers (75\%) are present in 7 or more different fishing ports. These results contrast with those concerning artisanal fisheries of SW Spain [26], where the identified métiers are located

\footnotetext{
${ }^{20}$ Real possibility in the short term of practicing a certain métier instead of another during the same season.
} 
in a few fishing ports. In Asturias, only those traditional métiers carried out in shallow waters close to the shore and targeting mainly crustaceans and anguilliformes (Anguilla pot and glass eel fishing) are restricted to some specific locations: these métiers (mostly traps) also present the highest seasonal pattern (whereas most of the net and longline gears are used during larger periods of the year), so specific appraisals must be carried out in case of Marine Protected Areas declaration or catches limits setting (TAC's, resource exploitation plans, etc.) affecting them, as negative impacts and economic losses at a local scale may be important.

Analyses of vessels' typologies have confirmed the existence of significant differences in terms of technical characteristics among vessels depending on the performed métiers. Although other South-European regional studies have found out that métiers are independent from vessel's size [32], some other have highlighted the existing relationships between vessels' size, other technical characteristics and the type of métiers used by smallscale boats [10] [11] [48] [49]. Findings in this research are in line with these studies and stress out that smaller vessels may be limited to exploit relatively seasonal fisheries surrounding the home ports, especially between January and March when adverse weather may put boats at risk. In addition to this, specific results on technical demands in this study provide researchers and managers useful information to carry out more accurate inferences about costs structures and output models for artisanal fleets, taking into account the technical demands of each métier. In terms of public policies design and budget provision, they help to assess up to what extent each métier is sensitive and need support from subsidies, training activities or security and qualification requirements.

Artisanal vessels have to decide on the métiers' choice in two time scales: daily (short-term) and annually (long-term), when they have to make investments in fishing gears. As it has been underlined by Tzanatos et al. [11], in the short-term, the choice of fishing tactics or métiers depends on multitude of factors: recent yield and income, market demand and price, seasonal availability of fishing grounds, tradition, skippers' experience, rumors about other fishermen yields, etc. Hence, changes in the biological or economic conditions results in a rapid redistribution of the fishing effort of artisanal fisheries [50], as it has been also shown in this case study throughout the high alternation between different métiers and gear types along one fishing season. Although the average landings weight was $99.19 \mathrm{~kg}$ and the average income was €396.65 per sale bill in 2009, Asturian artisanal métiers showed significant differences: the rod-hook targeting Scomber scombrus is the métier that generates the highest weight (1468 kg) and income (€886), being also important the Merluccius longline and gillnet métier (an average income of $€ 434$ and $€ 425$ respectively per fishing day) and the Lophius trammel net métier (€423), whereas $50 \%$ of Asturian active artisanal métiers registered an average income per fishing day under $€ 350$ in 2009. These results provide useful information that could guide artisanal fisheries managers and decision makers in the future allocation of ITQ's or the current distribution of TAC's, as well as they constitute valuable data to assess potential losses (and compensation measures) for vessels affected by certain management measures or environmental disasters.

These findings reflect that annual fishing effort is distributed among an "optimal" combination of métiers for each vessel, according to boats characteristics, expected annual profitability and fishing possibilities in the area, given the existing regulatory framework, so there is some margin of flexibility to adapt fishing decisions to changes in fish stocks, limitations of catches or increases in costs. This information constitutes a valuable baseline for further research focused on the assessment of multi-output models and productivity magnitudes, or the modeling of fishermen profit maximization.

The long-term decisions, what can be considered as fishing strategies, are affected by different considerations. As it was revealed in this case study, artisanal fishing patterns within Asturian fleet are changing significantly in the last years, and some of the identified métiers are nowadays in disuse or barely employed. Although the final choice of available gears may be limited by the lack of experience in some of them [51], ship-owners face mainly a cost-benefit question regarding what would be the best investment in fishing gears. Answers obtained through the interviewing process have shown that the diversity of métiers performed by the Asturian artisanal fleet nowadays are being reduced and tend to concentrate in those ones with higher net profit rates: as Garcíade-la-Fuente et al. [12] have recently shown, the estimated profitability of nets clearly surpasses hooks, lines and traps artisanal métiers incomes. As an example, ship-owners have stated that despite that high yield and income traditionally generated by longlines, the bait costs have increased greatly over the last years, pushing down the final profitability of such métiers. As a consequence, many vessels have recently invested in trammel net gears (Lophius trammel net) as they present relatively lower exploitation costs. It constitutes a clear example of how fishing tactics and effort may vary over time, which suggests a new sustainable management challenge: it must be evaluated the social and environmental role of artisanal métiers with low economic profitability in order to 
support them through the current fishing policy. At the same time, environmental sustainability of artisanal net métiers should be increasingly monitored, as they are becoming more and more used.

Two final issues arise from these results. On the one hand, public authorities and fishing guilds should pay special attention to find and implement management and commercial/diversification strategies to support those artisanal métiers with low economic profitability but high level of environmental and social sustainability. On the other hand, although analyses in other Spanish artisanal fisheries have shown a low level of discards (averaging just $4.13 \%$ of the total weight according to Forcada et al. [10], and some experiments specifically carried out with Asturian artisanal métiers as the Mullus gillnet [52] have shown that only $7.9 \%$ of the total catch weight is discarded, an increasing attention must be paid to artisanal net métiers selectivity, given that they become even more important among the Asturian artisanal fleet, so evaluation (and regulation) of "good practices" for an environmentally sustainable fishing activity could be recommendable.

It is hoped the present identification and characterization of Asturian artisanal métiers helps future management measures for artisanal fisheries. Nevertheless, exploring the pattern of métier rotation throughout longer time series would provide useful insights of the artisanal fishing activity and changes on fishing effort distribution [10] [48]. As well, improving knowledge on variable fishing tactics over the years, reasons and motivations explaining switching between métiers are considered key issues that deserve further research for the forecast and sustainable management of fishing effects on exploited stocks. In addition to this, it is necessary to highlight that future research will have to take into consideration total catches (including discards and unsold captures) in order to properly assess the fishing effort exerted by artisanal vessels at a regional scale. Moreover, it will be desirable to have available other kind of artisanal fisheries data in the near future, provided by logbooks or vessels monitoring systems (VMS) [16] that considerably increase accuracy and information about métiers effort in this region.

\section{Conclusions}

A métier-based approach is very useful to understand the spatio-temporal patterns of fishing effort allocation and catches, as well as to design and implement specific management measures based upon a good knowledge on the characteristics and problems of each métier. Although the problem of identifying métiers in the SouthEuropean area has been traditionally addressed in fisheries research, limitations on fishing data concerning vessels under 12 metres have excluded most of artisanal boats from many relevant analyses. Thus, when accurate, reliable and quantitative information on spatial and temporal fishing patterns for most of artisanal vessels is not available, many studies have applied alternative approaches as onboard samples or surveying methods to identify and characterize métiers, even though these sources mainly provide qualitative information and also have reliability problems. In this context, there is no precedent in exploring the potential of other sources of information to identify and characterize métiers in poor-data artisanal fisheries.

This study was aimed at achieving a detailed and updated characterization of the main technical, biological and economic issues concerning the métiers currently used by the artisanal fishing fleet of Asturias, an Atlantic region located in Northwest Spain. To reach this goal, a novel approach using administrative data on fishing licenses combined with daily sales registers and information collected through a surveying process has been applied. A value added of this approach, in poor-data contexts, is that it allows reaching highly disaggregated and detailed artisanal metier identification and classification, which comprehend all the richness and diversity of métiers practiced by these types of boats, and provides higher resolution than other classification frameworks. In the present case study, where the regional fleet is mainly artisanal and involved over 230 vessels in 2009 (70\% of the whole fleet), applying this method required a detailed analysis of the regional administrative register of artisanal fishing licences used per day and vessel in the region during a whole year (more than 14000 fishing operations).

As a result, 21 métiers were identified, 16 of which were fully active in 2009. Findings have outlined the strong coastal, close-to-port character of the Asturian artisanal fleet, as well as a high annual rotation of fishing métiers and gears types that confirms its polyvalence and versatility. Nonetheless, certain métiers are used extensively by the artisanal fleet, producing the major part of landings and revenues of these vessels: Lophius trammel net and Merluccius longline generate the $28.6 \%$ of landings and $43.1 \%$ of the total income generated by artisanal fisheries in 2009. In terms of spatial distribution, the identified métiers are located in several fishing ports covering broad geographical areas: 12 of the active métiers (75\%) are present in 7 or more different fishing 
ports. Only a few traditional métiers carried out in shallow waters close to the shore (as Anguilla pot and glass eel fishing) are restricted to some specific locations: these métiers (mostly traps) also present the highest seasonal pattern (whereas most of the net and longline gears are used during larger periods of the year). From an economic point of view, results by vessel typology have confirmed the existence of significant differences in terms of technical characteristics and workforce demands among vessels depending on the performed métiers. Additionally, although the average landings weight was $99.19 \mathrm{~kg}$ and the average income was $€ 396.65$ per sale bill in 2009, Asturian artisanal métiers showed significant differences: the rod-hook targeting Scomber scombrus is the métier that generates the highest weight (1468 kg) and income (€886), being also important the Merluccius longline and gillnet métier (an average income of $€ 434$ and $€ 425$ respectively per fishing day) and the Lophius trammel net métier (€423). Another interesting output of this research is that artisanal fishing patterns within Asturian fleet have changed significantly in the last years, and some of the identified métiers are nowadays in disuse or barely employed: as nets register lower exploitation costs than hooks, lines and traps, many vessels have recently invested in trammel net gears (Lophius trammel net).

The discussion of some findings in this article lead to other questions linked to the design of specific sustainable management measures in the context of South-European artisanal fisheries. Firstly, when highly heterogeneous artisanal vessels represent a relevant part of the whole fleets, management and planning measures should be designed and implemented taking into account métiers heterogeneity and the high level of internal complexity of artisanal fleets, avoiding grouping these vessels together within the same "uniform" category (i.e. named "Artes menores" in Spain, "Only passive gears" at a European scale, etc.). Secondly, it was confirmed that some vessels are limited to exploit relatively seasonal fisheries surrounding the home ports, especially when adverse weather may put boats at risk; given their constraints to redistribute their fishing effort, certain artisanal métiers (as glass eel fishing) and other fishing activities (as goose barnacle recollection, Pollicipes pollicipes), play in these periods a fundamental role as alternative/subsidiary fishing activities, when it is difficult and unprofitable to carry out another métiers. They become strategic at a local scale, as they provide income stability along the year to many artisanal fishermen. Finally, as part of the artisanal fleet is concentrating its activity on trammel net gears, a métier-diversity reduction is happening in parallel to a progressive cease of certain métiers; this changes suggest new sustainable management challenges: it should be evaluated the social and environmental role of artisanal métiers with low economic profitability in order to support them throughout the current fishing policy, whereas artisanal net métiers should be increasingly monitored in order to preserve the environmental sustainability of artisanal coastal fisheries.

\section{Acknowledgements}

This study was carried out within the PRESPO Project and co-funded by the European Regional Development Fund (ERDF) and the General Directorate of Maritime Fisheries of Asturias (Regional Ministry). Additionally, authors would like to thank Fishermen Guilds for their active collaboration and participation. Finally, we would like to thank reviewers for their detailed comments and insightful suggestions for the manuscript.

\section{References}

[1] FAO (2005) Increasing the Contribution of Small-Scale Fisheries to Poverty Alleviation and FOOD Security. FAO Technical Guidelines for Responsible Fisheries 10, Rome.

[2] Stergiou, K.I., Moutopoulos, D.K., Soriguer, M.C., Puente, E., Lino, P.G., Zabala, C., Monteiro, P., Errazkin, L.A. and Erzini, K. (2006) Trammel Net Catch Species Composition, Catch Rates and Métiers in Southern European Waters: A Multivariate Approach. Fisheries Research, 79, 170-182. http://dx.doi.org/10.1016/j.fishres.2006.03.003

[3] Tzanatos, E., Dimitriou, E., Papaharisis, L., Roussi, A., Somarakis, S. and Koutsikopoulos, C. (2006) Principal Socio-Economic Characteristics of the Greek Small-Scale Coastal Fishermen. Ocean and Coastal Management, 49, 511527. http://dx.doi.org/10.1016/j.ocecoaman.2006.04.002

[4] European Parliament (2012) On Small-Scale Coastal Fishing, Artisanal Fishing and the Reform of the Common Fisheries Policy. Fisheries Committee Report A7-0291/2012, Rapporteur João Ferreira.

[5] Florido del Corral, D. (2008) Focusing on Artisanal Fleets in a New Scenario: The Case of Andalusia (Spain). Marine Policy, 32, 1004-1012. http://dx.doi.org/10.1016/j.marpol.2008.02.007

[6] Gómez, S., Lloret, J., Riera, V. and Demestre, M. (2006) The Decline of the Artisanal Fisheries in Mediterranean Coastal Areas: The Case of Cap de Creus (Cape Creus). Coastal Management, 34, 217-232. 
http://dx.doi.org/10.1080/08920750500531389

[7] European Commission (2001) Green Paper on the Future of the Common Fisheries Policy. COM (2001) 135, Brussels.

[8] Farrugio, H., Oliver, P. and Biagi, F. (1993) An Overview of the History, Knowledge, Recent and Future Research Trends in Mediterranean Fisheries. Scientia Marina, 57, 105-119.

[9] García-Flórez, L., Morales, J., Gaspar, M.B., Castilla, D., Mugerza, E., Berthou, P., García de la Fuente, L., Oliveira, M., Moreno, O., García del Hoyo, J.J., Arregi, L., Vignot, C., Chapela, R. and Murillas, A. (2014) A Novel and Simple Approach to Define Artisanal Fisheries in Europe. Marine Policy, 44, 152-159. http://dx.doi.org/10.1016/j.marpol.2013.08.021

[10] Forcada, A., Valle, C., Sánchez-Lisazo, J.L., Bayle-Sempere, J.T. and Corsi, F. (2010) Structure and Spatio-Temporal Dynamics of Artisanal Fisheries around a Mediterranean Marine Protected Area. ICES Journal of Marine Science, 67, 191-203. http://dx.doi.org/10.1093/icesjms/fsp234

[11] Tzanatos, E., Somarakis, S., Tserpes, G. and Koutsikopoulos, C. (2006) Identifying and Classifying Small-Scale Fisheries Métiers in the Mediterranean: A Case Study in the Patraikos Gulf, Greece. Fisheries Research, 81, 158-168. http://dx.doi.org/10.1016/j.fishres.2006.07.007

[12] García-de-la-Fuente, L., González-Álvarez, J., García-Flórez, L., Fernández-Rueda, P. and Alcázar-Álvarez, J. (2013) Relevance of Socioeconomic Information for the Sustainable Management of Artisanal Fisheries in South Europe. A Characterization Study of the Asturian Artisanal Fleet (Northern Spain). Ocean and Coastal Management, 86, 61-71. http://dx.doi.org/10.1016/j.ocecoaman.2013.05.007

[13] Biseau, A. (1998) Definition of a Directed Fishing Effort in a Mixed-Species Trawl Fishery, and Its Impact on Stock Assessments. Aquatic Living Resources, 11, 119-136. http://dx.doi.org/10.1016/S0990-7440(98)80109-5

[14] Laurec, A., Biseau, A. and Charuau, A. (1991) Modelling Technical Interactions. ICES Marine Science Symposia, 193, 225-236.

[15] Mesnil, B. and Shepherd, J.G. (1990) A Hybrid Age- and Length- Structured Model for Assessing Regulatory Measures in Multiple-Species, Multiple-Fleet Fisheries. Journal du Conseil International Pour l'Exploration de la Mer, 47, 115-132. http://dx.doi.org/10.1093/icesjms/47.2.115

[16] Russo, T., Parisi, A., Prorgi, M., Boccoli, F., Cignini, I., Tordoni, M. and Cataudella, S. (2011) When Behaviour Reveals Activity: Assigning Fishing Effort to Métiers Based on VMS Data Using Artificial Neural Networks. Fisheries Research, 111, 53-64. http://dx.doi.org/10.1016/j.fishres.2011.06.011

[17] Ulrich, C. and Andersen, B.S. (2004) Dynamics of Fisheries, and the Flexibility of Vessel Activity in Denmark between 1989 and 2001. ICES Journal of Marine Science, 61, 308-322. http://dx.doi.org/10.1016/j.icesjms.2004.02.006

[18] Cabrera, J.L. and Defeo, O. (2001) Daily Bioeconomic Analysis in a Multispecific Artisanal Fishery in Yucatan, Mexico. Aquatic Living Resources, 14, 19-28. http://dx.doi.org/10.1016/S0990-7440(00)01094-9

[19] Oliveira, M.M., Camanho, A.S. and Gaspar, M.B. (2014) Enhancing the Performance of Quota Managed Fisheries Using Seasonality Information: The Case of the Portuguese Artisanal Dredge Fleet. Marine Policy, 45, 114-120. http://dx.doi.org/10.1016/j.marpol.2013.11.014

[20] Pascual, M., Borja, A., Galparsoro, I., Ruiz, J., Mugerza, E., Quincoces, I., Murillas, A. and Arregi, L. (2013) Total Fishing Pressure Produced by Artisanal Fisheries, from a Marine Spatial Planning Perspective: A Case Study from the Basque Country (Bay of Biscay). Fisheries Research, 147, 240-252. http://dx.doi.org/10.1016/j.fishres.2013.06.010

[21] Castro, J., Punzón, A., Pierce, G.J., Marín, M. and Abad, E. (2010) Identification of Métiers of the Northern Spanish Coastal Bottom Pair Trawl Fleet by Using the Partitioning Method CLARA. Fisheries Research, 102, 184-190. http://dx.doi.org/10.1016/j.fishres.2009.11.011

[22] Castro, J., Marín, M., Pierce, G.J. and Punzón, A. (2011) Identification of Métiers of the Spanish Set-Longline Fleet Operating in Non-Spanish European Waters. Fisheries Research, 107, 100-111. http://dx.doi.org/10.1016/j.fishres.2010.10.013

[23] Holley, J. and Marchal, P. (2004) Fishing Strategy Development under Changing Conditions: Examples from the French Offshore Fleet Fishing in the North Atlantic. ICES Journal of Marine Science, 61, 1410-1431. http://dx.doi.org/10.1016/j.icesjms.2004.08.010

[24] Jiménez, M.P., Sobrino, I. and Ramos, F. (2004) Objective Methods for Defining Mixed-Species Trawl Fisheries in Spanish Waters of the Gulf of Cádiz. Fisheries Research, 67, 195-206. http://dx.doi.org/10.1016/j.fishres.2003.09.048

[25] Murawski, S.A., Lange, A.M., Sissenwine, M.P. and Mayo, R.K. (1983) Definition and Analysis of Multispecies Otter-Trawl Fisheries off the Northeast Coast of the Unites States. Journal du Conseil International Pour l'Exploration de la Mer, 41, 13-27. http://dx.doi.org/10.1093/icesjms/41.1.13

[26] Silva, L., Gil, J. and Sobrino, I. (2002) Definition of Fleet Components in the Spanish Artisanal Fishery of the Gulf of Cádiz (SW Spain ICES Division IXa). Fisheries Research, 59, 117-128.

http://dx.doi.org/10.1016/S0165-7836(01)00420-9 
[27] Ulrich, C., Gascuel, D., Dunn, M.R., Le Gallic, B. and Dintheer, C. (2001) Estimation of Technical Interactions Due to the Competition for Resource in a Mixed-Species Fishery, and the Typology of Fleets and Métiers in the English Channel. Aquatic Living Resources, 14, 267-281. http://dx.doi.org/10.1016/S0990-7440(01)01132-9

[28] Castro, J., Abad, E., Artetxe, I., Cardador, F., Duarte, R., García, D., Hernández, C., Marín, M., Murta, A., Punzón, A., Quincoces, I., Santurtún, M., Silva, C. and Silva, L. (2007) Identification and Segmentation of Mixed-Species Fisheries Operating in the Atlantic Iberian Peninsula Waters. IBERMIX Project. European Commission, Directorate-General for Fisheries and Maritime Affairs (Contract Ref.: FISH/2004/03-33).

[29] Marchal, P., Ed. (2006) Technological Developments and Tactical Adaptations of Important EU Fleets (TECTAC No. QLK5-2001-01291). Final Project Report.

[30] Guillou, A., Lespagnol, P. and Ruchon, F. (2002) La pêeche aux petits métiers en Languedoc-Roussillon en 2000-2001. Convention de Participation au Programme PESCA (PIC), DIRAM-IFREMER No. 00/3210040/YF.

[31] Jabeur, C., Gobert, C. and Missaoui, H. (2000) Typologie de la flottille de pêche côtière dans le golfe de Gabès (Tunisie). Aquatic Living Resources, 13, 421-428. http://dx.doi.org/10.1016/S0990-7440(00)01069-X

[32] Tzanatos, E., Dimitriou, E., Katselis, G., Georgiadis, M. and Koutsikopoulos, C. (2005) Composition, Temporal Dynamics and Regional Characteristics of Small-Scale Fisheries in Greece. Fisheries Research, 73, 147-158. http://dx.doi.org/10.1016/j.fishres.2004.12.006

[33] O’Donnell, K.P., Molloy, P.P. and Vincent, A.C.J. (2012) Comparing Fisher Interviews, Logbooks, and Catch Landings Estimates of Extraction Rates in a Small-Scale Fishery. Coastal Management, 40, 594-611. http://dx.doi.org/10.1080/08920753.2012.727734

[34] Neis, B., Schneider, D.C., Felt, L., Haedrich, R.L., Fisher, J. and Hutchins, J.A. (1999) Fisheries Assessment: What Can Be Learned from Interviewing Resource Users? Canadian Journal of Fisheries and Aquatic Sciences, 56, 19491963. http://dx.doi.org/10.1139/f99-115

[35] European Commission (2008) Commission Decision (2008/949/EC) of 6 November 2008. Adopting a Multiannual Community Programme Pursuant to Council Regulation (EC) No. 199/2008 Establishing a Community Framework for the Collection, Management and Use of Data in the Fisheries Sector and Support for Scientific Advice Regarding the Common Fisheries Policy. Official Journal of the European Union, L 346/37.

[36] Martin, Q., Cabrero, M.T. and de Paz, Y. (2007) Tratamiento estadístico de datos con SPSS. Thomson Editores, Spain.

[37] Gibbons, J.D. (1985) Nonparametric Methods for Quantitative Analysis. American Sciences Press, New York.

[38] Battaglia, P., Romeo, T., Consoli, P., Scotti, G. and Andaloro, F. (2010) Characterization of the Artisanal Fishery and Its Socio-Economic Aspects in the Central Mediterranean Sea (Aeolian Islands, Italy). Fisheries Research, 102, 87-97. http://dx.doi.org/10.1016/j.fishres.2009.10.013

[39] Colloca, F., Crespi, V., Cerasi, S. and Coppola, S.R. (2004) Structure and Evolution of the Artisanal Fishery in a Southern Italian Coastal Area. Fisheries Research, 69, 359-369. http://dx.doi.org/10.1016/j.fishres.2004.06.014

[40] Merino, G., Morales-Nin, B., Maynou, F. and Grau, A.M. (2008) Assessment and Bioeconomic Analysis of the Majorca (NW Mediterranean) Trammel Net Fishery. Aquatic Living Resources, 107, 99-107. http://dx.doi.org/10.1051/alr:2008027

[41] Punzón Merino, A. and Gancedo Crespo, R.M. (2000) Descripción de las pesquerías artesanales de Cantabria y Asturias (Norte de España). Informes Técnicos (Instituto Español de Oceanografía), 179, 3-43.

[42] Freire, J. and García-Allut, A. (2000) Socioeconomic and Biological Causes of Management Failures in European Artisanal Fisheries: The Case of Galicia (NW Spain). Marine Policy, 24, 375-384. http://dx.doi.org/10.1016/S0308-597X(00)00013-0

[43] Batista, M.I., Teixeira, C.M. and Cabral, H.N. (2009) Catches of Target Species and Bycatches of an Artisanal Fishery: The Case Study of a Trammel Net Fishery in the Portuguese Coast. Fisheries Research, 100, 167-177. http://dx.doi.org/10.1016/j.fishres.2009.07.007

[44] Erzini, K., Gonçalves, J.M.S., Bentes, L., Moutopoulos, D.K., Hernando, J.A., Soriguer, M.C., Puente, E., Errazkin, L.A. and Stergiou, K.I. (2006) Size Selectivity of Trammel Nets in Southern European Small-Scale Fisheries. Fisheries Research, 79, 183-201. http://dx.doi.org/10.1016/j.fishres.2006.03.004

[45] Gonçalves, J.M.S., Stergiou, K.I., Hernando, J.A., Puente, E., Moutopoulos, D.K., Arregi, L., Soriguer, M.C., Vilas, C., Coelho, R. and Erzini, K. (2007) Discards from Experimental Trammel Nets in Southern European Small-Scale Fisheries. Fisheries Research, 88, 5-14. http://dx.doi.org/10.1016/j.fishres.2007.06.017

[46] García-Rodríguez, M., Fernández, Á.M. and Esteban, A. (2006) Characterization, Analysis and Catch Rates of the Small-Scale Fisheries of the Alicante Gulf (SE Spain) over a 10 Years Time Series. Fisheries Research, 77, $226-238$. http://dx.doi.org/10.1016/j.fishres.2005.09.002

[47] Puente, E. and Astorkiza, I. (2002) Estudio técnico-pesquero y socioeconómico de las pesquerías artesanales del País Vasco. Colección ITSASO 25, AZTI-Tecnalia. 
[48] Le Pape, O. and Vigneau, J. (2001) The Influence of Vessel Size and Fishing Strategy on the Fishing Effort for Multispecies Fisheries in Northwestern France. ICES Journal of Marine Science, 58, 1232-1242. http://dx.doi.org/10.1006/jmsc.2001.1121

[49] Guyader, O., Berthou, P., Koutsikopoulos, C., Alban, F., Demanèche, S., Gaspar, M.B., Eschbaum, R., Fahy, E., Tully, O., Reynal, L., Curtil, O., Frangoudes, K. and Maynou, F. (2013) Small Scale Fisheries in Europe: A Comparative Analysis Based on a Selection of Case Studies. Fisheries Research, 140, 1-13. http://dx.doi.org/10.1016/j.fishres.2012.11.008

[50] Holland, D.S. and Sutinen, J.G. (1999) An Empirical Model of Fleet Dynamics in New England Trawl Fisheries. Canadian Journal of Fisheries and Aquatic Sciences, 56, 253-264. http://dx.doi.org/10.1139/f98-169

[51] Salas, S., Sumaila, U.R. and Pitcher, T. (2004) Short-Term Decisions of Small-Scale Fishers Selecting Alternative Target Species: A Choice Model. Canadian Journal of Fisheries and Aquatic Sciences, 61, 374-383.

[52] Fernández-Rueda, M.P., Alcázar, J.L., Jiménez, F., Herrador, R., Muñoz, A. and García-Flórez, L. (2012) Catch Composition, Discards and Selectivity in the Red Mullet (Mullus surmuletus) Gillnet Fishery of the Asturias Coast. 13th International Symposium on Oceanography of the Bay of Biscay (ISOBAY 13), Santander, 11-13 April 2012, 150. http://www.ieo-santander.net/isobay13/documentos/posters/poster150_mpfernandezrueda.pdf 